\title{
Drainage Morphometric Analysis of a Catchment of Upper Hasdeo Subbasin using Remote Sensing and Geographical Information System (GIS) Technique
}

\author{
Karnika Dwivedi* and M.P. Tripathi \\ Department of Soil \& Water Engineering, SV College of Agricultural Engineering and \\ Technology \& Research Station, Faculty of Agricultural Engineering, Indira Gandhi Krishi \\ Vishwavidyalaya Raipur - 492012, Chhattisgarh, India \\ *Corresponding author
}

\section{A B S T R A C T}

Keywords

Morphometric, Surface drainage networks, GIS, Linear aspects

Article Info

Accepted:

17 October 2019

Available Online:

10 November 2019
This study deals with the Drainage Morphometric Analysis of a catchment of upper Hasdeo Subbasin. Morphometric analysis describes the basin geometry which provides a understanding of geological and geometric history of drainage basin. Geographical Information System and Remote sensing has becoming an efficient tool for water resource management planning. Morphometric analysis of Manendragarh watershed of Hasdeo sub-basin was carried out in the Department of Soil and Water engineering, Faculty of Agricultural Engineering, Indira Gandhi Krishi Vishwavidyalaya Raipur. Manendragarh watershed covers an area of about 1023 sq. km and has $\mathrm{VI}^{\text {th }}$ order streams. Strahler's method of stream ordering which is the most common used method has used in this study.

\section{Introduction}

The net productivity of crops depends on the proper management and utilization of two basic natural resources i.e. land and water. Out of these two basic natural resources, water is very important, which is becoming a scarce resource for agricultural production in almost all places across the glove. To overcome the water related problems, extensive care should be given to the operation and management of reservoirs and watersheds. Hydrologic and water quality investigations are fundamental to any watershed management programme.

Morphometric analysis can be done by measuring linear and shape of drainage network Biswas et al., (1999), Javed et al., (2011), Patel et al., (2013). Thematic layers are prepared by the application of remote 
sensing for morphometric analysis. Morphometric analysis provides the geometry of basin which provides the understanding of geometric and geological history of drainage basin (Strahler, 1957). Many similar studies have reported by Nautiyal, (1994), Biswas et al., (2002), Ratnam et al., (2005), Garde, (2006), Narendra and Nageswararao (2006), Mishra et al., (2007), Chitraet al., (2011).

The main objectives of this work was to performed morphometric analysis of Manendragarh watershed of upper Hasdeo sub-basin and find out their different characteristic with the help of various parameter viz., streams number, streams order, streams length, mean streams length, bifurcation ratios, circularity ratio, elongation ration, relief ratio, shape factor, drainage density, stream frequency, length of overland flow, constant channel maintenance, texture ratio, etc. using the remote sensing and GIS.

\section{Materials and Methods}

\section{Description of study area}

The study area of Manendragarh watershed of upper Hasdeo sub-basin was selected for study. Manendragarh watershed lies between latitude $23^{\circ} 0^{\prime} \mathrm{N}$ to $23^{\circ} 45^{\circ} \mathrm{N}$ and Longitude $81^{0} 50^{\prime} \mathrm{E}$ to $82^{\circ} 48^{\prime} \mathrm{E}$ (Fig. 1) and covers an area of $1023.939 \mathrm{Km}^{2}$

\section{Database and Methodology}

The base map has prepared from topographic map with scale 1:50000.Topographical maps were rectified/referenced geographically and mosaicked and entire study area was delineated in GIS environment with the help of Arc-GIS 10 software assigning Universal Transverse Mercator (UTM), World Geodetic System (WGS dating from 1984).SRTM (30m) data was used in this study to extract drainage network and analysis of
Morphometric parameters. Hydrology tool under Spatial Analyst Tools in ArcGIS10 software was used to extract drainage channels, and other parameters. The automated method for delineating streams followed a series of steps i.e. DEM, fill, flow accumulation, stream order and drainage network to extract and delineate drainage procedure describe in Figure 2(a) 2(b) and figure 3. Map creation, Scanning, Georeferencing, Spatial data and Topology creation are the steps involved in the morphometric analysis of Hasdeo River. The various morphometric parameters were computed using standard methodology (Table $1)$.

\section{Results and Discussions}

\section{Morphometric characteristics}

An effort was made to calculate various morphometric parameters such as stream order, stream number, stream length, bifurcation ratio, drainage density, form factor, elongation ratio, circularity ratio, compactness constant etc.

\section{Linear aspects of the basin}

\section{Stream order}

The designation of stream orders is the first step in drainage analysis and is based on hierarchic ranking of streams. In the present study, ranking of the streams is carried out based on the method proposed by Strachler (1964).

The order of the basin is the order of the highest stream. In the present case study, the watershed is of $6^{\text {th }}$ order. It was found that as the stream order increases the frequency decreases. The stream order and the total number of stream segments in each order for the basin are shown in Table 2 . 


\section{Stream number $(\mathrm{Nu})$}

Stream number is the number of stream segments of various orders. It is inversely proportional to the stream order. ArcGIS 10 was used for calculating steam number.

Total 680no of streams were identified out of which 337was found to be in first order, 163 was in second order, 78 was in third order,60 was in fourth order, 40 was in fifth order and 2 was in sixth order respectively (Table 2). The higher amount of stream order indicates lesser permeability and infiltration (Strahler, 1964).

\section{Bifurcation ratio $\left(\mathbf{R}_{\mathbf{b}}\right)$}

It is the ratio of the number of streams of a given order $(\mathrm{Nu})$ to the number of streams of the next higher order $(\mathrm{Nu}+1)$.

$R_{b}=\frac{N_{u}}{N_{u+1}}$

Horton (1945) considered the bifurcation ratio as an index of relief and directions. Lower value of the $\mathrm{Rb}$ is characteristics of basin which have suffered less structural disturbances (Strahler, 1964).

Table 2, clearly shows that the bifurcation ratio values for the Manendragarh watershed varies from 1.30 to 20 with the mean bifurcation ratio of 4.49 and the highest $R_{b}$ was in stream order $6^{\text {th }}$.

\section{Stream length $\left(\mathbf{L}_{\mathbf{u}}\right)$}

Total stream length is the length of all the streams having order $u$. It is indicative of the contributing area of the basin of that order. The stream length of different order wise was computed based on the law proposed by Horton (1945). The stream length of study area varies from $570.72 \mathrm{~km}$ to $2.33 \mathrm{~km}$ (Table 3).

\section{Mean stream length $\left(\mathrm{L}_{\mathrm{sm}}\right)$}

The total stream length divided by the number of stream segments of that order gives the mean stream length of that order (Table 3 ).

\section{Stream length ratio $\left(\mathrm{L}_{\mathrm{ur}}\right)$}

It is defined as the total stream length of one order to the next lower order of stream segment.

$R_{l}=\frac{L_{u}}{L_{u-1}}$

Horton's law (1945) of stream length states that mean stream length segments of each of the successive orders of a basin tends to appropriate a direct geometric series with streams length increasing towards higher order streams. The value of $\mathrm{L}_{\mathrm{ur}}$ was vary from 0.65 to 1.24 (Table 3 ).

\section{Length of overland flow $\left(L_{g}\right)$}

It is the largest length of the flow stream from the starting point of runoff water up to that point of the catchment where runoff is not available to flow the outlet.

The length of overland flow ( $\left.\mathrm{L}_{\mathrm{g}}\right)$ approximately equals to half of the reciprocal of drainage density (Horton, 1945).The length of overland flow of Manendragarh watershed is 0.56kilometers (Table 4).

\section{Aerial aspect of drainage basin}

\section{Basin area (A)}

Basin area is the direct outcome of the drainage development in a particular basin. The rate of runoff depends on its area and physiography. Larger the area, smaller is the runoff and vice versa. 


\section{Perimeter (P)}

Length boundary of a basin is known as the perimeter of the basin. The basin parameter dependent on elongation ratio and circulatory ratio.

\section{Drainage density $\left(\mathbf{D}_{\mathrm{d}}\right)$}

Drainage density is defined as a ratio of total length of all streams to the total area of the basin. Horton (1932) introduced drainage density into literature as an expression to indicate the closeness of spacing of channels. The drainage density of the Manendragarh watershed was found to be $1.11 \mathrm{~km} / \mathrm{km}^{2}$ respectively.

\section{Stream frequency $\left(F_{s}\right)$}

The stream frequency is the number of streams per unit area of the basin. It mainly depends upon the litho-logy of the basin and reflects the texture of the drainage network. It is a good indicator of drainage pattern. The stream frequency $\left(\mathrm{F}_{\mathrm{s}}\right)$ of the whole basin is 0.66 (Table 4).

\section{Texture ratio $\left(\mathbf{R}_{t}\right)$}

It is the total number of stream segment of all orders per perimeter of that area (Horton, 1945). Horton recognized infiltration capacity as the single important factor which influences Texture ratio $\left(\mathrm{R}_{\mathrm{t}}\right)$ and considered the drainage texture to include drainage density and drainage frequency. Table 2 shows that in Texture ratio $\left(R_{t}\right)$ of the study area was found to be 2.09 .

\section{Circularity ratio $\left(\mathbf{R}_{\mathbf{c}}\right)$}

It is the ratio of area of the basin to the area of circle having the same circumference as the perimeter $(\mathrm{P})$ of the basin (Miller, 1953).

$$
R_{c}=\frac{A}{4 \pi \times P}
$$

It is influenced more by the length, frequency and gradient of streams of various orders than slope condition and drainage pattern of the basin (Strahler, 1957). The Circularity ratio of the study area was found to be 0.04 (Table 4).

\section{Form factor ratio $\left(\mathbf{R}_{\mathbf{f}}\right)$}

Basin shape can be indexed by simple dimensionless ratios of the basic measurements of area, perimeter and length (Thornbury, 1969).

It is defined as the ratio of basin area to square of the basin length (Horton, 1932). The form factor ratio value of the basin was low, 0.04 .

\section{Elongation ratio $\left(\mathbf{R}_{\mathrm{e}}\right)$}

Elongation ratio is defined as the ratio of diameter of a circle of the same area as the basin to the maximum basin length.

$R_{e}=\frac{2 R}{L_{b}}$

Values close to 1.0 are typical of very low relief, where as in the range 0.6-0.8 are usually associated with the high relief and steep ground slope (Schumm, 1964).

The value of $R_{\mathrm{e}}$ in the study area was found to be 0.22 (Table 4 ).

\section{Relief aspects of drainage basin}

\section{Maximum watershed relief $(\mathbf{H})$}

It is the maximum vertical distance between the lowest and highest points of watershed. It is also known as total relief. 
Table.1 Empirical relationships used in analysis of morpho-metric parameters and formula

\begin{tabular}{|c|c|c|}
\hline $\begin{array}{l}\text { Morphometric } \\
\text { parameter }\end{array}$ & Formula & Reference \\
\hline \multicolumn{3}{|c|}{ Linear Aspects } \\
\hline Stream order & Hierarchial rank & Strahler (1964) \\
\hline Stream length $\left(\mathbf{L}_{\mathbf{u}}\right)$ & Length of stream & Horton (1945) \\
\hline $\begin{array}{l}\text { Mean stream length } \\
\left(\mathbf{L}_{\mathrm{sm}}\right)\end{array}$ & $\begin{array}{c}\mathrm{L}_{\mathrm{sm}}=\mathrm{L}_{\mathrm{u}} / \mathrm{N}_{\mathrm{u}} \\
\text { where, } \mathrm{L}_{\mathrm{sm}}=\text { mean stream length } \\
\mathrm{L}_{\mathrm{u}}=\text { Total stream length of order ' } \mathrm{u} \text { ' } \\
\mathrm{N}_{\mathrm{u}}=\text { Total no. of stream segments of order ' } \mathrm{u} \text { ' }\end{array}$ & Strahler, 1964) \\
\hline $\begin{array}{l}\text { Stream length ratio } \\
\left(\mathrm{L}_{\mathbf{u r}}\right)\end{array}$ & $\begin{array}{c}\mathrm{L}_{\mathrm{ur}}=\mathrm{L}_{\mathrm{u}} / \mathrm{L}_{\mathrm{u}-1} \\
\text { where, } \mathrm{L}_{\mathrm{ur}}=\text { stream length ratio } \\
\mathrm{L}_{\mathrm{u}}=\text { mean of stream length of order ' } \mathrm{u} \text { ' } \\
\mathrm{L}_{\mathrm{u}-1}=\text { mean of stream length of its next lower } \\
\text { order }\end{array}$ & Horton (1945) \\
\hline Bifurcation ratio $\left(\mathbf{R}_{\mathbf{b}}\right)$ & $\begin{array}{c}\mathrm{R}_{\mathrm{b}}=\mathrm{N}_{\mathrm{u}} / \mathrm{N}_{\mathrm{u}+1} \\
\mathrm{R}_{\mathrm{b}}=\text { Bifurcation ratio } \\
\mathrm{N}_{\mathrm{u}}=\text { Total no. of stream segments of order ' } \mathrm{u} \text { ' } \\
\mathrm{N}_{\mathrm{u}+1}=\text { no. of stream segments of the next } \\
\text { higherorder }\end{array}$ & Schumn (1956) \\
\hline $\begin{array}{l}\text { Mean bifurcation } \\
\quad \text { ratio }\left(\mathbf{R}_{\mathrm{bm}}\right)\end{array}$ & $\mathrm{R}_{\mathrm{bm}}=$ Average of bifurcation ratios of all orders & Strahler (1957) \\
\hline $\begin{array}{l}\text { Length of overland } \\
\text { flow }\left(L_{g}\right)\end{array}$ & $\begin{aligned} & \mathrm{Lg}=1 / 2 \mathrm{D}_{\mathrm{d}} \\
& \text { where, } \mathrm{L}_{\mathrm{g}}=\text { Length of overland flow } \\
& \mathrm{D}_{\mathrm{d}}=\text { Drainage density }\end{aligned}$ & Horton (1945) \\
\hline Basin length $\left(\mathbf{L}_{\mathbf{b}}\right)$ & $\begin{aligned} L_{b} & =1.321 A^{0.568} \\
\text { where, } \mathrm{A} & =\text { Area of the basin }\end{aligned}$ & $\begin{array}{l}\text { Nookaratnam } \\
\quad(2005)\end{array}$ \\
\hline Basin Perimeter (P) & $\begin{array}{l}\text { Outer boundary of drainage basin measured in } \\
\text { kilometers. (GIS software analysis) }\end{array}$ & Schumn(1956) \\
\hline \multicolumn{3}{|c|}{ Areal Aspects } \\
\hline Drainage density $\left(D_{d}\right)$ & $\begin{array}{c}\mathrm{D}_{\mathrm{d}}=\mathrm{L}_{\mathrm{u}} / \mathrm{A} \\
\text { where, } \mathrm{D}_{\mathrm{d}}=\text { Drainage density } \\
\mathrm{L}_{\mathrm{u}}=\text { Total stream length of all orders } \\
\mathrm{A}=\text { Area of basin }\left(\mathrm{km}^{2}\right)\end{array}$ & Horton (1945) \\
\hline Basin Area (A) & $\begin{array}{l}\text { Area from which water drains to a common } \\
\text { stream. (GIS software analysis) }\end{array}$ & Strahler (1964) \\
\hline Stream frequency $\left(F_{s}\right)$ & $\begin{array}{c}\mathrm{F}_{\mathrm{s}}=\mathrm{N}_{\mathrm{u}} / \mathrm{A} \\
\text { where } \mathrm{F}_{\mathrm{s}}=\text { Stream frequency } \\
\mathrm{N}_{\mathrm{u}}=\text { Total no. of streams of all orders } \\
\mathrm{A}=\text { Area of basin }\left(\mathrm{km}^{2}\right)\end{array}$ & Horton (1932) \\
\hline Texture ratio $\left(\mathbf{R}_{\mathbf{t}}\right)$ & $\begin{array}{c}\mathrm{R}_{\mathrm{t}}=\mathrm{N}_{\mathrm{u}} / \mathrm{p} \\
\text { where, } \mathrm{R}_{\mathrm{t}}=\text { Texture ratio } \\
\mathrm{N}_{\mathrm{u}}=\text { Total no. of streams of all orders } \\
\mathrm{P}=\text { Perimeter }(\mathrm{km})\end{array}$ & Horton (1945) \\
\hline $\begin{array}{l}\text { Infiltration Number } \\
\text { (If) }\end{array}$ & $\begin{array}{c}\mathrm{D}_{\mathrm{d}} \times \mathrm{F}_{\mathrm{s}} \\
\text { Where, } \mathrm{D}_{\mathrm{d}}=\text { Drainage density }\left(\mathrm{Km} / \mathrm{Km}^{2}\right) \text { and } \mathrm{F}_{\mathrm{s}}= \\
\text { Drainage frequency. }\end{array}$ & Zavoiance (1985) \\
\hline
\end{tabular}




\begin{tabular}{|c|c|c|}
\hline Form factor $\left(\mathbf{R}_{\mathrm{f}}\right)$ & $\begin{array}{c}\mathrm{R}_{\mathrm{f}}=\mathrm{A} / \mathrm{L}_{\mathrm{b}}^{2} \\
\text { where, } \mathrm{A}=\text { Area of basin }\left(\mathrm{km}^{2}\right) \\
\mathrm{L}_{\mathrm{b}}^{2}=\text { Square of basin length }\end{array}$ & Horton (1932) \\
\hline Shape factor $\left(B_{s}\right)$ & $\begin{array}{c}\mathrm{B}_{\mathrm{s}}=\mathrm{L}_{\mathrm{b}}^{2} / \mathrm{A} \\
\text { where, } \mathrm{L}_{\mathrm{b}}=\text { Square of basin length } \\
\mathrm{A}=\text { Area of basin }\left(\mathrm{km}^{2}\right)\end{array}$ & $\begin{array}{l}\text { Nookaratnam } \\
\text { (2005) }\end{array}$ \\
\hline Circulatory ratio $\left(\mathbf{R}_{\mathrm{c}}\right)$ & $\begin{array}{c}\mathrm{R}_{\mathrm{c}}=4 \times \pi \times \mathrm{A} / \mathrm{P}^{2} \\
\text { where, } \mathrm{R}_{\mathrm{c}}=\text { circulatory ratio } \\
\mathrm{A}=\text { Area of basin }\left(\mathrm{km}^{2}\right) \\
\mathrm{P}=\text { Square of the perimeter }(\mathrm{km})\end{array}$ & Miller (1953) \\
\hline Elongation ratio $\left(\mathbf{R}_{\mathrm{e}}\right)$ & $\begin{array}{c}\mathrm{R}_{\mathrm{e}}=(4 \mathrm{xA} / \pi)^{0.5} / \mathrm{L}_{\mathrm{b}} \\
\text { where, } \mathrm{Re}=\text { Elongation Ratio } \\
\mathrm{A}=\text { Area of basin }\left(\mathrm{km}^{2}\right) \\
\mathrm{L}_{\mathrm{b}}=\text { Basin length }\end{array}$ & Schumn (1956) \\
\hline $\begin{array}{l}\text { Compactness constant } \\
\qquad\left(\mathbf{C}_{\mathrm{c}}\right)\end{array}$ & $\begin{array}{c}\mathrm{C}_{\mathrm{c}}=0.2821 \mathrm{P} / \mathrm{A}^{0.5} \\
\text { where, } \mathrm{A}=\text { Area of basin }\left(\mathrm{km}^{2}\right) \\
\mathrm{P}=\text { Perimeter }(\mathrm{km})\end{array}$ & Horton (1945) \\
\hline $\begin{array}{c}\text { Constant channel } \\
\text { maintenance }(C)\end{array}$ & $\begin{array}{c}\mathrm{C}=1 / \mathrm{D}_{\mathrm{d}} \\
\text { where, } \mathrm{D}_{\mathrm{d}} \text { Drainage density }\end{array}$ & Schumn (1956) \\
\hline \multicolumn{3}{|c|}{ ReliefAspects } \\
\hline $\begin{array}{l}\text { Ruggedness Number } \\
\qquad\left(\mathbf{R}_{\mathbf{n}}\right)\end{array}$ & $\begin{array}{c}\mathrm{R}_{\mathrm{n}}=\mathrm{D}_{\mathrm{d}} *(\mathrm{H} / 1000) \\
\mathrm{R}_{\mathrm{n}}=\text { Ruggedness number } \\
\text { where, Dd=Drainage density and } \\
\mathrm{H}=\text { Basin relief }(\mathrm{m})\end{array}$ & Strahler (1956) \\
\hline Relief Ratio & $\begin{array}{c}\mathrm{R}_{\mathrm{hl}}=\mathrm{H} / \mathrm{L}_{\mathrm{b}} \\
\mathrm{R}_{\mathrm{hl}}=\text { Relief ratio } \\
\text { where, } \mathrm{H}=\text { Basin relief }(\mathrm{m}) \text { and } \mathrm{L}_{\mathrm{b}}=\text { Basin length }\end{array}$ & Schumn (1956) \\
\hline
\end{tabular}

Table.2 Stream order, streams number, and bifurcation ratios of Manendragarh watershed

\begin{tabular}{|c|c|c|c|c|c|}
\hline $\mathrm{S}_{\mathrm{u}}$ & $\mathrm{N}_{\mathrm{u}}$ & $\mathrm{R}_{\mathrm{b}}$ & $\mathrm{N}_{\mathrm{u}-\mathrm{r}}$ & $\mathrm{R}_{\mathrm{b}} * \mathrm{~N}_{\mathrm{u}-\mathrm{r}}$ & $\mathrm{R}_{\mathrm{bwm}}$ \\
\hline 1 & 337 & & & & 2.65 \\
\hline 2 & 163 & 2.07 & 500 & 1033.74 & \\
\hline 3 & 78 & 2.09 & 241 & 503.63 & \\
\hline 4 & 60 & 1.30 & 138 & 179.40 & \\
\cline { 1 - 5 } 5 & 40 & 1.50 & 100 & 150.00 & \\
\hline 6 & 2 & 20.0 & 42 & 840.00 & \\
\hline Total & 680 & 26.96 & 1021.00 & 2706.77 & \\
Mean & 113.33 & $4.49 *$ & & & \\
\hline & & & & & \\
\hline
\end{tabular}

$\mathrm{S}_{\mathrm{u}}$ : Stream order, Nu: Number of Streams

$\mathrm{R}_{\mathrm{b}}$ : Bifurcation ratios, Rbm: Mean bifurcation ratio*,

$\mathrm{N}_{\mathrm{u}-\mathrm{r}}$ : Number of streams used in the ratio,

$\mathrm{R}_{\mathrm{bwm}}$ : Weighted mean bifurcation ratio 
Table.3 Stream length, and stream length ratio in Manendragarh watershed

\begin{tabular}{|c|c|c|c|c|c|c|c|}
\hline $\mathrm{S}_{\mathrm{u}}$ & $\mathrm{L}_{\mathrm{u}}$ & $\mathrm{N}_{\mathrm{u}}$ & $\mathrm{L}_{\mathrm{u}} / \mathrm{S}_{\mathrm{u}}$ & $\mathrm{L}_{\mathrm{ur}}$ & $\mathrm{L}_{\mathrm{ur}-\mathrm{r}}$ & $\mathrm{L}_{\mathrm{ur}} *\left(\mathrm{~L}_{\mathrm{ur}-\mathrm{r}}\right)$ & $\mathrm{L}_{\mathrm{uwm}}$ \\
\hline 1 & 570.72 & 337 & 1.69 & & & & \\
\hline 2 & 277.53 & 163 & 1.70 & 1.01 & 848.25 & 852.81 & \\
\hline 3 & 132.25 & 78 & 1.70 & 1.00 & 409.78 & 408.06 & \\
\hline 4 & 86.06 & 60 & 1.43 & 0.85 & 218.31 & 184.67 & 0.99 \\
\hline 5 & 71.10 & 40 & 1.78 & 1.24 & 157.16 & 194.78 & \\
\hline 6 & 2.33 & 2 & 1.16 & 0.65 & 73.43 & 48.04 & \\
\hline Total & 1139.99 & 680 & & & & & \\
\hline Mean & & & & $0.95 *$ & & & \\
\hline
\end{tabular}

Su: Stream Order, Lu: Stream Length

$\mathrm{L}_{\mathrm{ur}}$ : Stream Length ratio, $\mathrm{L}_{\mathrm{urm}}$ : Mean Stream Length ratio*

$\mathrm{L}_{\mathrm{ur}-\mathrm{r}}$ : Stream Length used in the ratio,

$\mathrm{L}_{\mathrm{uwm}}$ : Weighted mean Length ratio Stream.

Table.4 Morphometric analysis of the study area

\begin{tabular}{|c|c|}
\hline Morphometric parameters & $\begin{array}{c}\text { Manendragarh } \\
\text { watershed }\end{array}$ \\
\hline Basin Area (sq. Km) & 1023.94 \\
\hline Total Number of Stream (Nu) & 680 \\
\hline Perimeter $(\mathbf{P}),(\mathbf{K m})$. & 545.10 \\
\hline Basin Length $\left(\mathrm{L}_{\mathbf{b}}\right),(\mathrm{Km})$. & 164.80 \\
\hline Elongation Ratio (Re) & 0.22 \\
\hline Texture Ratio $\left(\mathbf{R}_{\mathrm{t}}\right)$ & 2.09 \\
\hline Mean Bifurcation Ratio $\left(\mathbf{R}_{\mathrm{bm}}\right)$ & 3.74 \\
\hline Drainage density $(\mathrm{D}),\left(\mathrm{Km} / \mathrm{Km}^{2}\right)$ & 1.11 \\
\hline Stream frequency $\left(F_{s}\right)$ & 0.66 \\
\hline Infiltration number $\left(\mathbf{I}_{\mathbf{f}}\right)$ & 0.74 \\
\hline Form factor $\left(\mathbf{R}_{\mathbf{f}}\right)$ & 0.04 \\
\hline Circulatory ratio $\left(\mathbf{R}_{c}\right)$ & 0.04 \\
\hline Length of overland flow $\left(\mathrm{L}_{\mathrm{g}}\right),(\mathrm{Km})$. & 0.56 \\
\hline Constant channel maintenance $(C)$ & 0.90 \\
\hline Compactness constant $\left(\mathbf{C}_{\mathrm{c}}\right)$ & 4.81 \\
\hline Shape factor $\left(B_{s}\right)$ & 26.52 \\
\hline Ruggedness Number & 0.704 \\
\hline Basin Relief (H), (m.) & 632.000 \\
\hline Relief Ratio $\left(\mathbf{R}_{\mathbf{h}}\right)$ & 3.83 \\
\hline
\end{tabular}


Fig.1 Location map of study area

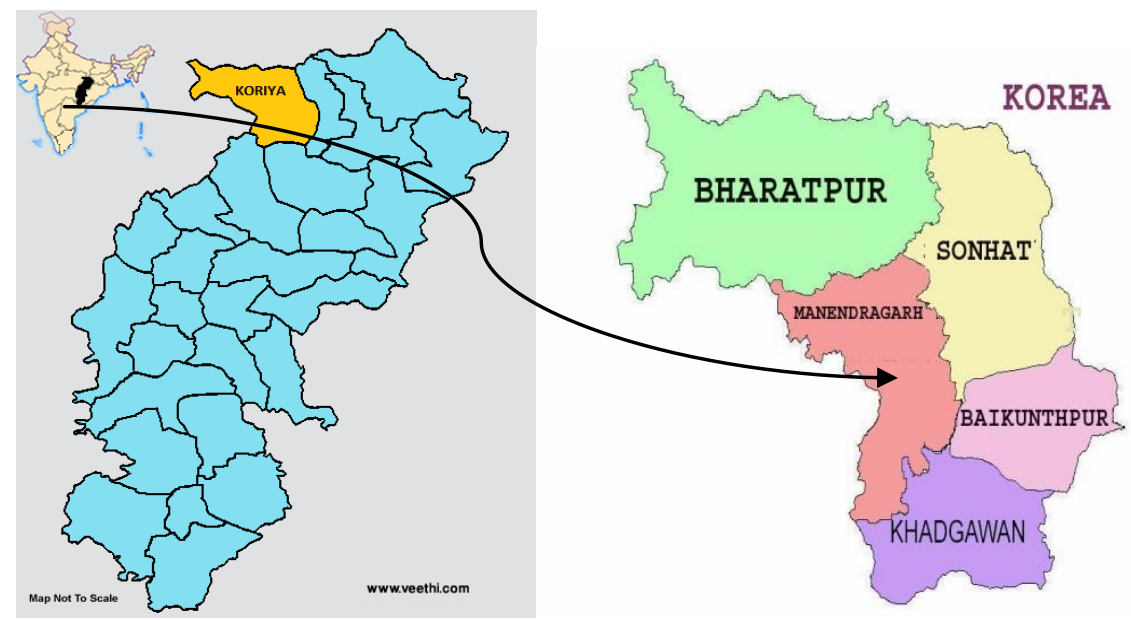

Fig.2(a) DEM map of study area

Fig.2(b) Drainage map of study area
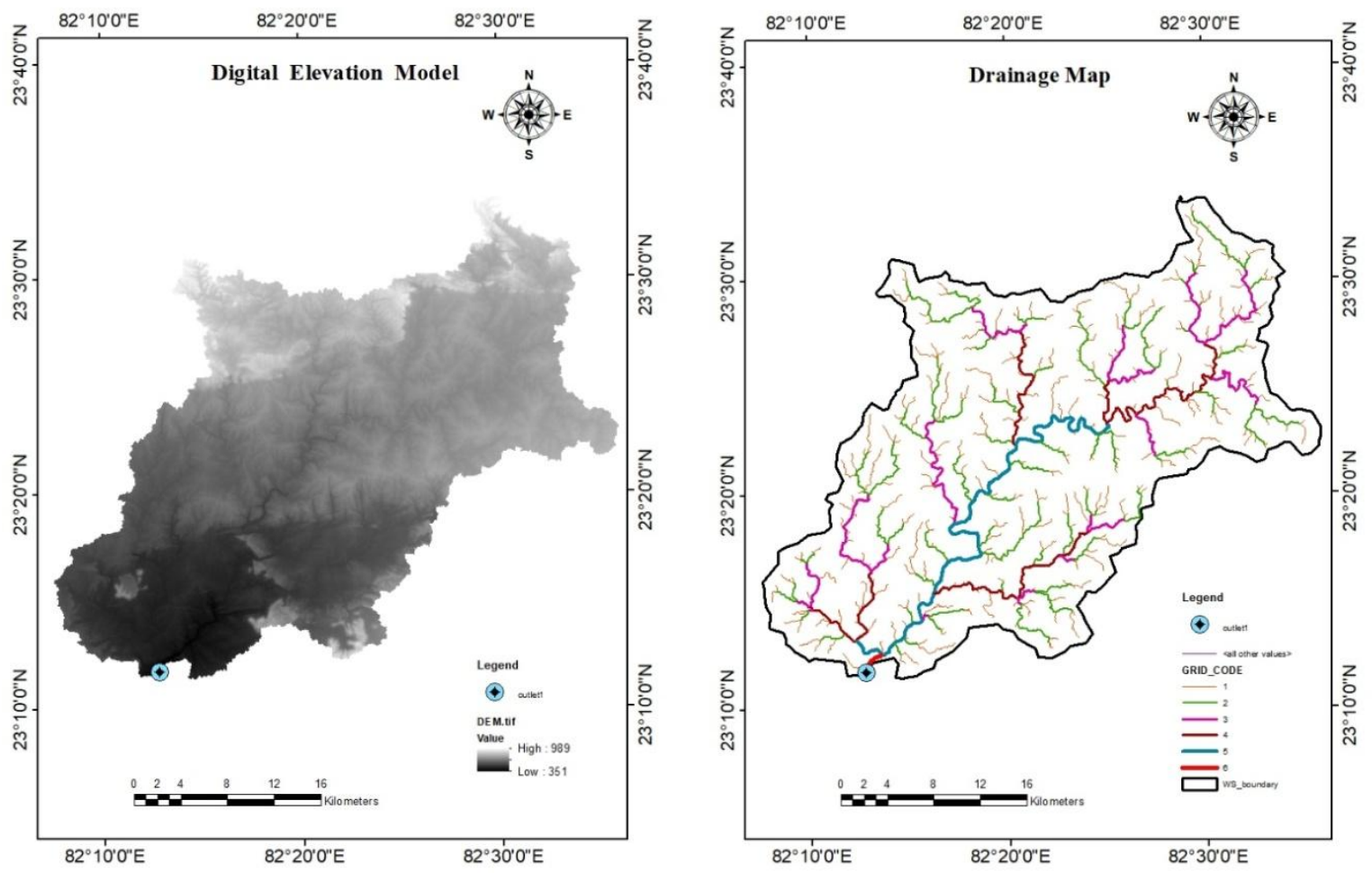
Fig.3 Extraction of drainage network of the study area of Hasdeo sub-basin
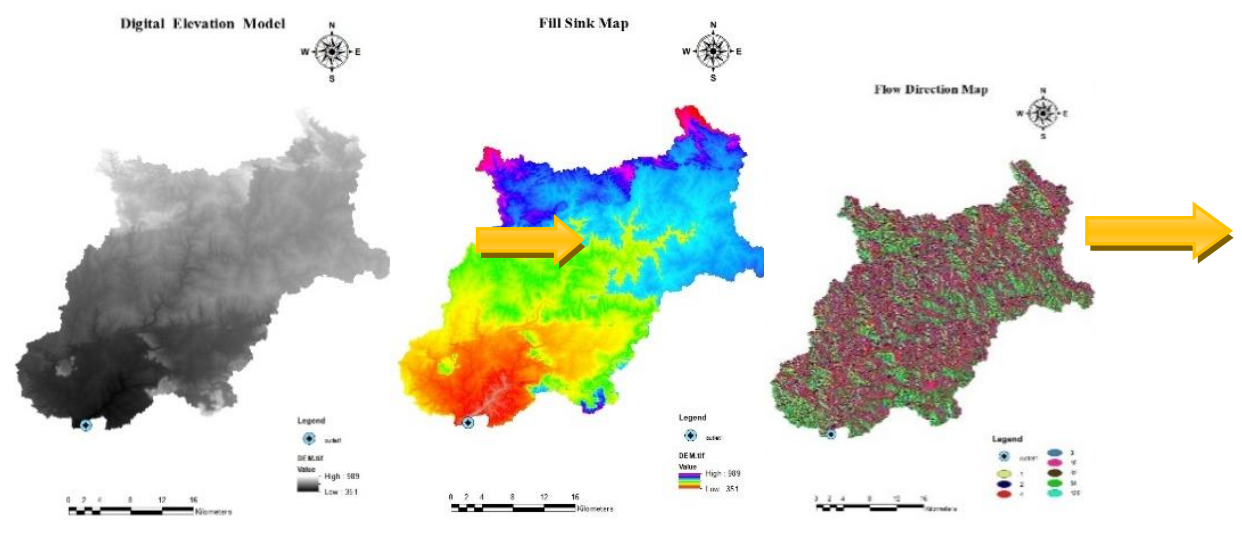

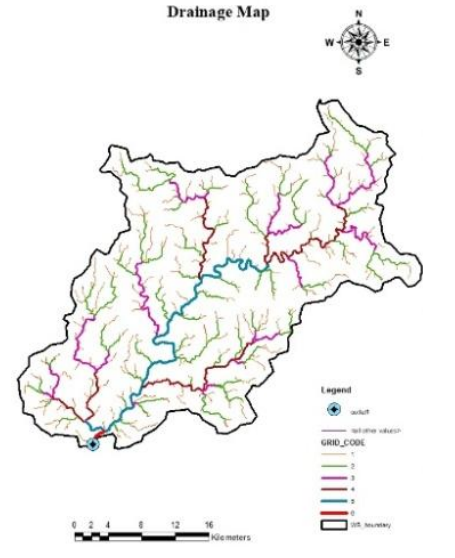

Flow Accumulation Map

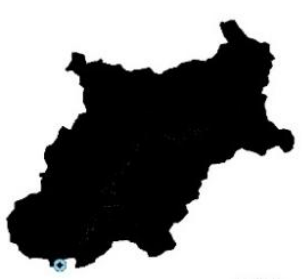

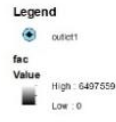

\section{Relief ratio $\left(\mathbf{R}_{\mathrm{h}}\right)$}

It is the total relief $(\mathrm{H})$ of watershed divided by maximum basin length (Lb). It is an indicator of potential energy available to move water and sediment down the slope.

$R_{h}=\frac{H}{L_{b}}$

\section{Ruggedness number $\left(\mathbf{R}_{\mathbf{n}}\right)$}

Ruggedness number is the product relief of basin $(\mathrm{H})$ and drainage density (Dd). It gives an idea of overall roughness of watershed.

$R_{n}=H \times D_{d}$
The Ruggedness Number of the Manendragarh watershed was 0.704 to be indicating that low value of ruggedness and basin implies that area is less prone to soil erosion and have intrinsic structural complexity in association with relief and drainage density.

\section{Relative relief $(\mathbf{R r})$}

It is the ratio of the maximum watershed relief to the perimeter of the watershed.

$$
R_{r}=\frac{H}{P}
$$


Morphological characteristic of a catchment was derived manually from topographic map of the watershed and Geographical Information System (GIS). In the study area, the value of relief ratio was 3.83 (Table 4).

\section{Compactness constant $\left(\mathrm{C}_{\mathrm{c}}\right)$}

The $\mathrm{C}_{\mathrm{c}}$ is independent of size of basin and dependent only on the shape. The compactness coefficient for study area was found to be 4.81 .

\section{Constant of channel maintenance (C)}

Schumn (1956) used the inverse of drainage density as a property termed as constant of channel maintenance. Similar to the drainage density, constant of channel maintenance depends on the basin relative relief, lithology, climate, etc. It decreases with increasing erodibility (Schumn, 1956). Constant of channel maintenance (C) value for Manendragarh watershed was found to be 0.90, shown in Table 4. Higher values suggest more area is required to produce surface flow which implies that part of water may get lost by evaporation, percolation etc.; lower value indicates less chances of percolation/infiltration and hence more surface runoff (Bhagwat et al., 2011).

Morphometric analysis of drainage system is prerequisite to any hydrologic study. The quantitative analysis of morphometric parameters is found to be of immense utility in river basin evaluation, watershed prioritization for soil and water conservation, and natural resources management at micro level. The study reveals that the integrated Remote Sensing and GIS based approach in evolution of Morphometric parameter is more appropriate and useful than conventional methods. The analysis of morphometric Parameters at river basin helpsus to understand the relationships among the different aspects of the drainage patterns and their influence on land forming processes, drainage, and land erosion properties. The drainage density and stream frequency are the decisive factor for the morphometric classification of drainage basins. These are the factors which describe the runoff pattern, sediment yield and other hydrological parameters of the drainage basin. The value of drainage density is $1.11 \mathrm{~km}^{-1}$ i.e below $1 \mathrm{~km}^{-1}$, which shows that low drainage density nature of basin. Thus, these studies are very useful for planning and drainage basin management.

\section{References}

Bhagwat, T.N., Shetty, A. and Hegde, V.S. 2011. Spatial variation in drainage characteristics and geomorphic instantaneous unit hydrograph (GIUH); implications for watershed managementA case study of the Varada River basin, Northern Karnataka. Catena 87: 52-59.

Biswas, S., Sudhakar, S. and Desai, V.R. (1999) Prioritization of Sub-Watersheds Based on Morphometric Analysis of drainage basin: A Remote Sensing and GIS approach, Journal of Indian Society of Remote Sensing, 27(3), pp 155-166.

Biswas, S., Sudhakar, S. and Desai, V.R. (2002), Remote sensing and geographic information system-based approach for watershed conservation. J. Survey Eng. ASCE, 108-124.

Chitra, C., Alaguraja, P., Ganeshkumari, K., Yuvaraj, D., and Manivel, M. 2011. Watershed characteristics of Kundah subbasin using remote sensing and GIS techniques. International Journal of geomatics and geosciences, 2(1), 311-335.

Garde, R. G. 2006. River Morphology. New Age International. New Delhi India.

Horton, R. E.1932. Drainage basin characteristics, Trans. Am. Geophys. Unon.13: pp 350361.

Horton, R.E. 1945. Erosional development of streams and their drainage basins; Hydro physical approach to quantitative 
morphology. Bulletin of Geological Society of America, 56, 275-370.

Javed, A., Khanday, M.Y. and Rias, S. (2011) Watershed Prioritization Using Morphometric and Land Use/Land Cove Parameters: A Remote Sensing and GIS Based Approach. Journal Geological Society of India, 78, 63-75.

Mageshet al., (2012).

Miller, V.C., 1953. A quantitative study of drainage basin characteristics in the mountain area. Virginia and Tennessee. Technical report. Office of Naval research, Department of Geology, Columbia University, New York.

Mishra, A., Kar, S., Singh, V. P., 2007, Prioritizing structural management by qualifying the effect of Land use and Land cover on Watershed runoff and sediment yield. Water Resource. Manage. 21, 18991913.

Nautiyal, M. D., 1994. Morphometric analysis of a drainage basin, District Dehradun, Uttar Pradesh. J. Indian Soc. Remote Sens. 22, 251-261.

Narendra, K., and Nageswararao, K. 2006. Morphometry of the meghadrigedda watershed, Visakhapatnam district, Andhra Pradesh using GIS and resources at data. Journal of the Indian Society of Remote Sensing, 34(2), 101-110.

Nookaratnam, K., Srivastava, Y.K., Venkateswarao, V., Amminedu, E. and Murthy, K.S.R., 2005. Check dam positioning by prioritization of micro- watersheds using SYI model and morphometric analysis-remote sensing and GIS perspective. Journal of the Indian Society of Remote Sensing 33 (1), 25-38.

Patel, D., Gajjar, C. and Srivastava, P. (2013) Prioritization of Malesari MiniWatersheds through Morphometric Analysis: A Remote Sensing and GIS Perspective. Environmental Earth Sciences, 69, 2643-2656.

Ratnam, K. N., Shrivastava, Y.K., Rao, V.V., Amminedu, E., Murthy, K.S.R., 2005. Check Dam positioning by prioritization of micro-watersheds using SYI model and Morphometric analysis- Remote sensing and GIS perspective. J. Indian Soc. Remote Sens. 33, 25-38.

Schumn, S.A., 1956. Evolution of drainage systems and slopes in badlands at Perth, Amboy, New Jersey. Geological Society of America, Bulletin. 67, 597-646.

Strahler, A., 1957. Quantitative analysis of watershed geomorphology. Transaction AGU 38, 913-920

Strahler, A. N. (1964). Quantitative geomorphology of drainage basins and channel networks. In: Chow V.T. (ed.), Handbook of Applied Hydrology. McGraw Hill Book Company, New York

Thornbury, W.D. 1969. Principles of Geomorphology. 2nd edition, Wiley and Sons, New York, USA.

Zavoiance, I. 1985. Morphometry of drainage basins (Developments in water science), Elsevier Science, New York, USA.

\section{How to cite this article:}

Karnika Dwivedi and Tripathi, M.P. 2019. Drainage Morphometric Analysis of A Catchment of Upper Hasdeo Subbasin using Remote Sensing and Geographical Information System (GIS) Technique. Int.J.Curr.Microbiol.App.Sci. 8(11): 1887-1897.

doi: https://doi.org/10.20546/ijcmas.2019.811.221 